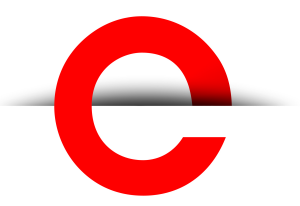

U T S

e PRES S
PORTAL Journal of Multidisciplinary International Studies

Vol. 17, No. 1/2

Jan 2021

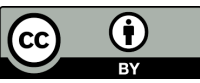

(C) 2021 by the author(s). This is an Open Access article distributed under the terms of the Creative Commons Attribution 4.0 International (CC BY 4.0) License (https:// creativecommons.org/ licenses/by/4.0/), allowing third parties to copy and redistribute the material in any medium or format and to remix, transform, and build upon the material for any purpose, even commercially, provided the original work is properly cited and states its license.

Citation: Balma-Tivola, C. 2021. Who are you? What do you do? What do you bring? A florin! On Reclusions, Dissidences, Mutual Aid, Kinships, and Irony during Italian Lockdown. PORTAL Journal of Multidisciplinary International Studies, 17:1/2, 79-84. http://dx.doi. org/10.5130/pjmis.v17i1$\underline{2.7423}$

ISSN 1449-2490 | Published by UTS ePRESS I http://epress. lib.uts.edu.au/ojs/index.php/ portal
ESSAY

\section{Who are you? What do you do? What do you bring? A florin!}

\section{On Reclusions, Dissidences, Mutual Aid, Kinships, and Irony during Italian Lockdown}

\author{
Cristina Balma-Tivola \\ Corresponding author: Cristina Balma Tivola, cbalmativoladgmail.com \\ DOI: http://dx.doi.org/10.5130/pjmis.v17i1-2.7423 \\ Article History: Received 12/09/2020; Accepted 20/11/2020; Published 28/01/2021
}

\begin{abstract}
This essay elaborates upon some ethnographic notes taken during informal participant observation by a freelance cultural anthropologist living in Turin (capital of Piedmont, one of the regions most affected by COVID-19) during the pandemic in Italy. The essay explores many issues faced by Italian residents during the lockdown, including inequality and grassroots initiatives, isolation conditions in a variety of contexts (home, prisons, retirement homes), stereotypes of Italians from abroad, the misunderstanding of personal distancing guidelines and the concept of family and community.
\end{abstract}

\section{Keywords}

Italy; Lockdown; Dissidence; Irony; Community; Mutual Aid

\section{Essential chronicle}

Phase 1 of the national lockdown to contain the spread of COVID-19 began in Italy on March 9, and consisted of the obligation to stay at home, the closure of all services, all commercial activities (excluding grocery stores, pharmacies and newsstands), jobs, schools, and social, cultural, religious activities, among others. Movement was prohibited except to find goods for survival. Encounters with family members not living together were also prohibited. 
Initially lasting one month, the lockdown was extended for a second month with the loosening of some restrictions (i.e. reopening stationery and clothing stores and allowing walks within 200 meters from home). On May 4, Phase 2 began and the government reopened commercial and cultural activities (if able to comply with sanitation requirements and physical distancing), public parks, and also allowed public sporting activities. Phase 3 finally began on June 15 when coexistence with the virus coincided with freedom of movement and action at the national level.

\section{Forms of Inequality}

Government measures were strictly observed. The risk of large fines and-more crucially-the shocking image of 60 coffins transported with a column of military vehicles from Bergamo to nearby cities for cremation, deterred potential offenders (see Berizzi 2020). The situation, however, was experienced in very different ways depending on one's place of residence, available home space, economic and social conditions, family situation and so on. It is not the same to be confined in a small apartment in the city, perhaps in close contact with family members and in precarious economic conditions, as to enjoy a large house, perhaps with a garden, by the sea, the mountains or the countryside, in solitude and without economic stress or work problems.

Italy's health care system, which is guaranteed to everybody, was the only egalitarianism I observed. Despite increasing privatisation since the " 80 s and initial priority unjustifiably given to VIPs and politicians at the onset of the COVID-19 crisis, we always had hope, albeit among a thousand difficulties, of being assisted. Other aspects of existence, such as economic and social conditions, work and education-all elements that put many people and families at risk of survival—were not adequately managed by regional and national governments. Social and personal fragilities were similarly ignored by state institutions until Phase 2.

\section{The Decree \#lorestoacasa: Plausible Measure of Protection or House Arrest?}

The decree that determined the national lockdown had the denomination \#Iorestoacasa [\#Istayhome] in the form of a hashtag. The only exception to isolation was the purchase of food, pharmaceutical products or newspapers. In all these cases, a special self-certification was needed to leave the house (a downloadable form from the Government website had to be filled in with personal data, time of exit, reasons and places of destination). Law enforcement agencies, and in some cases even the army, had set up checkpoints to verify the plausibility of people's excuses to leave their homes. Ironically, this prompted citizens to think of the sketch by Massimo Troisi and Roberto Benigni in the film Nothing Left to Do but Cry (1984), in which the two are listlessly interrogated by a customs officer who concludes his rhetorical questions with a request for a florin to let them pass. Although the decree was national, its application was partly left to the regions, whose regional presidents enforced it, sometimes sensibly, and at other times in authoritarian ways (see Romanelli 2020).

In Piedmont, high penalties were imposed on individuals who flouted the rules bordering on the grotesque and accompanied by the continuous refrain from the regional President that we were in a situation of war.'To define the pandemic in such a way is incorrect because it creates a distorted reality as many intellectuals pointed out in their public speeches at that time. But above all it authorises the possibility of the state establishing special laws to deprive the citizenship of political and social rights, and even to abuse of the state instruments of control.

And yet, many of my acquaintances and I, seeing the satisfaction of the councillors at the reeling in of the numbers of (albeit very rare) transgressors, and in their encouragement of citizens to report individuals circulating on the streets to the police, began to feel a great discomfort. The same councillors were not 
U T S

e P R E S S

making any real effort to properly manage the situation. They did not provide solutions for the very serious shortage of personal protective equipment both in hospitals and in stores. They did not invest in providing resources to hospitals. Nor did they design any plan or implement any measure to protect the most vulnerable people. While observing the lockdown guidelines, many of us took advantage of the few guaranteed rights of movement to enjoy a daily walk, to meet our friends, and to bring help to people in fragile conditions.

\section{Strategies of Dissidence, that is: How we Managed to Get Out Anyway}

The first week of lockdown in Italy was broadcast worldwide. The classic stereotype of Italians as a people characterised by the need for sociality that takes every opportunity to party was confirmed to be correct. The decree relegated citizens home but did not prevent them from using balconies to go out, sing, play and hang colourful rainbows accompanied by the words 'everything will be fine.' Italians' infamy for breaking rules was evidenced by using the excuse of walking the dog to explain their outings, excuses that reached such absurd heights that the Sardinian town of Mamoiada felt obliged to specify that the dog should be alive.

Those who decided to leave their home following the decree had to, as indicated, fill in a form to justify why they were going out. I moved from time to time on foot, by bicycle, or by car, enjoying a city where the air was finally clean and the noises muffled. Dramatically, the only remaining sound, with a certain continuity, was that of the ambulances, which continuously brought to mind the real situation far from the apparent idyll. On the form I indicated the places where I would go to satisfy basic needs for myself and my family, and I indicated a distance of 3 kilometres, justifying it with the need to find special food for my fragile health. In this way, I would guarantee myself every day a walk of a few kilometres, where I could meet friends and acquaintances, and also my partner who lives one kilometre away from me on the road to the market.

This strategy, to partially lie on the form to extend the distance and time of the outings, allowed people to bring help to their fellow citizens in situations with no institutional support. Even though it was to remedy the absolute shortcomings on the part of the institutions, it was still an illegal act.

\section{Reclusions, Inconveniences, Massacres}

At the beginning of the pandemic, the detainees in Italian prisons rioted due to overcrowding and the impossibility of being protected by sanitation and distancing measures, causing twelve fatalities (see F.Q. 2020). In the absence of alternatives, the government will decide in the future the possibility of detainees serving sentences under house arrest for those convicted of minor crimes. Inexplicably, the 376 detained under 'High Security 3' for mafia crimes will also benefit from this opportunity. The decision is now under investigation by the magistrates (see Pipitone 2020 and Abbate 2020).

The situation is quite different in the Permanent Centres for Repatriation (CPR), where migrants remain imprisoned without any possibility of being guaranteed the abovementioned measures of protection of their health and are completely isolated from the outside. In Turin not even the complaint of Monica Gallo, Guarantor of the City for the rights of detainees, will be heard by those in charge (see Parisotto 2020).

The requests for support from elderly people, families with disabled people, people suffering from mental distress or serious psychiatric disorders, and homeless people, have not been heard and they all remain without home care, day and night centres, and outpatient services. In addition, there are now those who, despite the absence of previous discomforts, find themselves unable to cope alone with anxiety, depression and stress. According to Giorgi (2020), at the end of the lockdown there will be 70 suicides directly related to the pandemic. Furthermore, the first two months of lockdown led to an increase in violence against women and children, exacerbated by forced cohabitation. But even here no measures are implemented 
to protect them. According to Lombardi (2020), at the end of the lockdown there will be 11 victims of femicide.

Several local administrations including Piedmont, Lombardy and Lazio used retirement homes as places of long-term care for COVID-19 patients, taking advantage of pre-existing buildings (although the rooms are not isolated and lack the necessary equipment for the proper management of such patients). Healthcare personnel already contracted for the care of elderly guests now suddenly find themselves managing COVID-19 patients without proper training (see Scacciavillani 2020; Barlozzari and Benignetti 2020; Di Benedetto 2020a and 2020b). This decision, which was taken without informing the families of the elderly, led to a large number of deaths and is now currently being investigated by the magistrates (see Bazzi 2020).

\section{Fragile citizens, and grassroots answers}

Italy is a country in which a significant part of the social support of the most fragile segments of the population is undertaken by associations and non-state bodies of various socio-cultural, political and religious orientations, sometimes in consortium with public institutions in charge of these functions, sometimes even replacing them.

In Turin, a large part of the support interventions for people in difficulty during Phase 1 consisted in providing food and basic necessities to those who were in precarious economic conditions and completely abandoned by public institutions that had closed. This action was carried out by both increasing the activity of public canteens in parishes and religious welfare organisations, and by distributing packages of basic necessities by associations and cooperatives and also radical squats (CSOA Gabrio, Prinz Eugen).

Initiatives from merchants included the provision of food boxes for those in need. Merchants used their locations as donation and distribution points to provide wooden boxes filled with food and other goods. These were often placed at bus stops and crossroads. Despite the risk of the food boxes being stolen by those who didn't need them, this strategy was successful because it was simple. With so many boxes in so many locations, anyone who went out to do the shopping would see them and perhaps put something in them. I myself spent several days riding my bike with my backpack to put rice, pasta, legumes (even on behalf of my family who stayed at home) in the boxes in my neighbourhood. Alone and on my bike, I was able to go unnoticed in a situation where leaving home without a valid excuse could be punished.

\section{Spacing, Social Relations, Relatives}

Another issue related to the government's management of the emergency was the conceptual misunderstanding of the term 'social distancing' that was used to refer to personal/physical distancing. This semantic misunderstanding had several consequences. Anthropologist Edward T. Hall's (1996) theory of proxemics distinguishes 'personal distance' (characterised by the interactions among good friends or family and reaching the distance of about $120 \mathrm{~cm}$ between two interlocutors) from 'social distancing' (characterised by the interactions among acquaintances and reaching the distance of about $370 \mathrm{~cm}$ between two interlocutors). Following Hall's prescription, it would have been much more correct to talk about 'personal distancing.'This confusion between a specific measure ('one meter physical distancing') and a blurred subjective concept such as that of 'social distancing,' deprived the citizens of their responsibility towards their own safety and of those around them and allowed the government and councillors to implement compulsory restrictions (see Bennato 2020).

The popular conflation of 'physical distance' as being some sort of 'social isolation,' led, in many cases, to dramatic loneliness-especially when intersecting with various fragilities by and beyond the pandemic.

People's need for sociality led to a tendency to talk to acquaintances who otherwise would be avoided. The cartoonist Zerocalcare, much loved and followed in Italy, drew a strip in which he asks the head of 
U T S

e PRES S the government to promulgate an amnesty once the pandemic is over, declaring we are all free to forget our promises to each other during the lockdown. Not surprisingly, we secretly felt a complicit joy when a motorist who visited his lover's residence during Phase 1 because he and his lover were unable to resist the desire, was stopped by police only when already on his way back home.

The pandemic invoked in me and in others the instinct to take care of our community. Hence, the baking of apple pies (always heartening) and gifting cuttings from my flowering plants to my neighbours, but also my adherence to online projects designed to provide company and a smile and a vision of human creativity.

\section{Congiunti/The Conjuncts}

During Phase 1 many of us resorted to the trick of making appointments at stores to see our friends. The Phase 2 decree on May 4 provided for the possibility of meeting among congiunti (literal translation: conjuncts). Who are conjuncts? Italian residents had to ask themselves the same question. This antiquated, unused and extremely formal term, refers to family members with whom you have a 'stable affection.'The possibility of only meeting with congiunti caused citizens to revolt, as they generally cared little about being able to meet an unknown third cousin and who instead wanted to see their friends. This government policy uncorked a bottle: from that moment we started meeting again, filling in the new self-certification form provided by the government with our own interpretation of the term, sometimes with hilarious results. An anthropologist colleague circulated a fake certification online in which patterns of clans and lineages were reproduced, questioning whether marriage was mono- or polygamous and residence matri- or patrilocal, and we invented all sorts of stable relationships that included bogus Sapphic relationships, undeclared adoptions and putative fraternities. Anything, in order to meet whom we considered our real 'family,' even without blood ties.

\section{Three months later}

To leave our region and/or go abroad, we had to enter Phase 3 at the beginning of June. But as the economic and human costs of the pandemic and the government's mishandling of the crisis became clearer, many of us experienced a deep distrust towards the government and councillors. A gap emerged between those who, despite the pandemic, still follow institutional initiatives, economic measures and strategies, and those who oppose or resist them.

Summer vacation mostly occurred within national borders, but wherever you moved there was always the shadow of the virus lurking. This risk has penetrated people's minds to such an extent that we now wear masks everywhere on our own initiative and we only meet loved ones who we know to be equally attentive.

What I hope for in the coming months is that we remain healthy and that this situation - if it must continue - will last so long that we will mature as a society, but not so much to destroy us as a community. My hope is that nothing returns as it was before, but that everything becomes much better than it was before.

Wouldn't that be a wonderful outcome for such a tragic event?

\section{References}

Abbate, L. 2020, 'Esclusivo: coronavirus, i mafiosi al 41bis lasciano il carcere e tornano a casa,' L'Espresso, 21 April. Online, available: https://espresso.repubblica.it/attualita/2020/04/21/news/capimafia-lasciano-il-carcerecoronavirus-1.347378 [Accessed 24 November 2020].

Barlozzari, E. \& Benignetti, A. 2020, “Anziani messi con i malati di Covid”. La denuncia nelle rsa del Lazio,' Il Giornale, 20 April. Online, available: https:/www.ilgiornale.it/news/roma/poche-mascherine-e-tamponi-ritardo-boom-contaginelle-rsa-1855941.html [Accessed 24 November 2020]. 
U T S

e PRES S
Bazzi, A. 2020, 'La regione Lombardia è nei guai per le RSA,' Il Post, 17 April. Online, available: https://www.ilpost. it/2020/04/17/regione-lombardia-rsa/ [Accessed 24 November 2020].

Bennato, D. 2020, 'I due paradossi del concetto di distanza sociale,' Progetto Forward. Online, available: https://forward. recentiprogressi.it/it/rivista/numero-18-distanza/articoli/i-due-paradossi-del-concetto-di-distanza-sociale/ [Accessed 24 November 2020].

Berizzi, P. 2020, 'Bergamo, non c'è più posto: 70 mezzi militari portano le salme fuori dalla regione,' La Repubblica, 18 March. Online, available: https:/www.repubblica.it/cronaca/2020/03/18/foto/bergamo non c e piu posto 70 mezzi militari portano le salme fuori dalla regione-251650969/1/ [Accessed 30 November 2020].

Di Benedetto, L. 2020a, 'Rsa, i morti per Covid-19. I numeri della strage', Panorama, 18 June. Online, available: https:// www.panorama.it/news/cronaca/rsa-morti-covid-19-numeri-anziani-dati [Accessed 24 November 2020].

Di Benedetto, L. 2020b, 'I perché della strage degli anziani nelle Rsa causa Covid-19,' Panorama, 29 June. Online, available: https://www.panorama.it/news/cronaca/cause-perche-strage-anziani-rsa-causa-covid-19 [Accessed 24 November 2020].

F.Q. 2020, 'Coronavirus, carceri in rivolta: 12 vittime. Nuovi disordini in alcuni penitenziari. A Foggia 19 evasi ancora in fuga. Previsto lo "sfollamento" di San Vittore. Indagini di più procure sulla “regia” delle rivolte,' Il Fatto Quotidiano, 9 March. Online, available: https://www.ilfattoquotidiano.it/2020/03/10/coronavirus-carceri-in-rivolta-altri-3-detenutimorti-a-rieti-nuove-proteste-a-siracusa-e-caserta-a-foggia-evasione-di-massa-23-ricercati-la-procura-di-milano-apreinchiesta-sulla-sommossa-a-san/5730183/ [Accessed 24 November 2020].

Giorgi, P. 2020, 'È allarme per i suicidi causati dal Covid,' Agenzia Italia, 7 September. https://www.agi.it/cronaca/ news/2020-09-07/allarme-psichiatri-suicidi-covid-9589799/ [Accessed 24 November 2020].

Hall, E. T. 1966, The Hidden Dimension. Anchor Books, New York.

Lombardi, M. 2020, 'Coronavirus, la strage in quarantena: undici donne uccise nei due mesi dell'emergenza,' Il Messaggero, 28 April. Online, available: https://www.ilmessaggero.it/mind the gap/coronavirus femminicidi undici donne uccise quarantena-5197142.html [Accessed 24 November 2020].

Parisotto, A. 2020, 'Coronavirus, il Cpr di corso Brunelleschi è una bomba a orologeria: "Il contagio lì sarebbe drammatico", Torinoggi, 24 March. Online, available: https:/www.torinoggi.it/2020/03/24/leggi-notizia/argomenti/ attualita-8/articolo/coronavirus-il-cpr-di-corso-brunelleschi-e-una-bomba-a-orologeria-il-contagio-li-sarebbe-dra.html [Accessed 24 November 2020].

Pipitone, G. 2020, 'Coronavirus, l'emergenza riporta a casa i mafiosi dal 41 bis: concessi i domiciliari al colonnello di Provenzano. Ora pure gli altri boss sperano. Di Matteo: "Lo Stato sembra cedere al ricatto delle rivolte," Il Fatto Quotidiano, 21 April. Online, available: https://www.ilfattoquotidiano.it/2020/04/21/coronavirus-lemergenza-riportaa-casa-i-mafiosi-dal-41-bis-concessi-i-domiciliari-il-colonnello-di-provenzano-ora-pure-gli-altri-boss-sperano-dimatteo-lo-stato-sembra-aver-ceduto-al-ricatto/5777616/ [Accessed 24 November 2020].

Romanelli, R. 2020, 'Costituzione calpestata dai DPCM di Conte, uomo solo al comando,' Il Riformista, 31 March. Online, available: https://www.ilriformista.it/costituzione-calpestata-dai-dpcm-di-conte-uomo-solo-al-comando72541/?refresh ce [Accessed 24 November 2020].

Scacciavillani, G. 2020, 'Coronavirus, in Lombardia pazienti Covid in Residenze per anziani. Sindacati: "Non è soluzione: non hanno spazi e mascherine”, Il Fatto Quotidiano, 19 March. Online available: https://www. ilfattoquotidiano.it/2020/03/19/coronavirus-in-lombardia-pazienti-covid-in-residenze-per-anziani-sindacati-non-esoluzione-non-hanno-spazi-e-mascherine/5741352/ [Accessed 24/11/2020]. 